\title{
Motivation to become a Foundation Phase teacher in South Africa
}

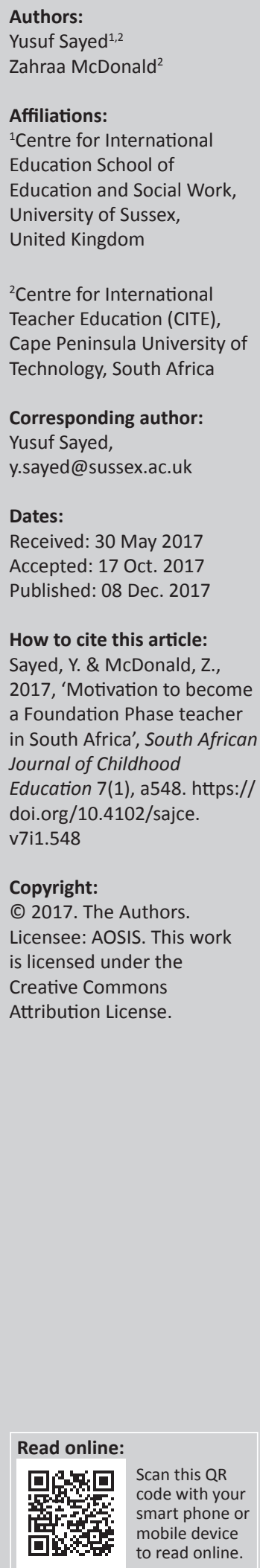

\begin{abstract}
Motivation to enter initial teacher education is a key concern in research globally and in South Africa specifically. Supply of teachers for the Foundation Phase is identified as a critical need in South Africa and understanding why individuals enter these programmes is crucial. In this context, this article explores what motivates student teachers to enter the Bachelor of Education in the Foundation Phase. Drawing on quantitative and qualitative data from a survey administered to first-year student teachers at three public higher education institutions in South Africa, this article examines the reasons why student teachers enrol in Foundation Phase Bachelor of Education initial teacher education programmes, highlighting the extrinsic and intrinsic reasons for doing so. The article concludes by drawing out the implications of the research into motivation to enter Foundation Phase teaching and how it relates to understanding and managing Foundation Phase teacher supply in South Africa.
\end{abstract}

\section{Introduction}

International studies (Kyriacou, Hultgren \& Stephens 1999; Thomson, Turner \& Nietfeld 2012) highlight the fact that effective schools are those that have good quality teachers. According to a review by the World Bank (2012):

a number of studies have found that teacher effectiveness is one of the most important school-based predictors of student learning and that several years of teaching by outstanding teachers can offset the learning deficits of disadvantaged students. (p. 1)

A range of studies that explore what makes school systems effective have looked for common characteristics in the top performing education systems, accounted by international achievement tests, with a view to identifying features that account for success (Mourshed, Chikjioke \& Barber 2010). These studies have reached similar conclusions. The key strategies they identify for improving student outcomes centre around developing a quality teacher workforce, which aims to:

- attract, recruit and retain high-quality candidates into teacher training

- train with extensive school-based practice

- train with high-level subject specialisation and academic rigour

- provide teachers with personalised continuing professional development (CPD) through mentoring and coaching

- involve teachers in research and education policymaking.

In the South African context, there are systemic concerns about attracting and recruiting the best teachers to redress the unequal apartheid legacy confounded by current inequalities in education. Teaching is not considered the most attractive career option. In addition, Van Broekhuizen (2015) and other researchers note several systemic challenges in teacher recruitment. These include balancing supply and demand, attracting the best into teaching, an ageing cohort of teachers which needs replacing, an oversupply in some fields or subjects and undersupply in others particularly in combinations of phases, subjects and language instruction.

A specific problem of teacher supply in South Africa is in the Foundation Phase. A recent estimate using a multivariate model suggested that there will be a negative gap of Foundation Phase teachers of between 15220 and 42135 by 2020, accumulating over the years from 2013 to 2019 (Green, Adendorff \& Mathebula 2014). The authors indicated that the public Higher Education (HE) system can be expected to produce no more than 3880 new Foundation Phase Initial Teacher Education (ITE) graduates in total by 2019.

Note: In this article the authors use the racial categories of white, black, coloured and Indian that the respondents identified themselves with as these are the dominant racial categories that marked apartheid and the inequities that the system engendered. The usage of these terms does not in way imply that we endorse racial categorisation and we argue that race is socially constructed and embedded in systems of privilege and inequity. 
There are several policy initiatives to deal with the recruitment challenges as these relate to attracting the best and in areas or subjects of need. These include Action Plan to 2019 [Department of Basic Education (DBE) 2015] and an Education Human Resource Planning Framework, which aims to guide efforts to provide the right quality and quantity of teachers and support staff, with the right qualifications and competencies, in the right positions, at the right time. Several specific supply side interventions such as the Teacher Rural Incentive Scheme (TRIS), the Funza Lushaka Bursary Programme (FLBP) and the Strengthening Foundation-Phase Teacher Education Programme (SFPTEP) seek to redress the problem by supporting teacher and students with funding and increasing research in the field.

The article thus asks the question of what motivates student teachers to enter the Bachelor of Education (B.Ed.) programme in the Foundation Phase, with the aim to draw out implications for the supply of Foundation Phase teachers. In order to address the question, data are presented from a survey administered to first-year B.Ed. Foundation Phase student teachers at three public HE institutions in South Africa. Understanding why individuals choose to enter teaching will shed light on developing a more balanced and equitably deployed teaching corps in which qualified and well paid educators are not disproportionately located in historically white and advantaged schools, but in those where they are needed most. Understanding why people become teachers is also crucial to finding ways to keep teachers in the teaching profession. The article begins by outlining the debates about teacher motivation, developing the theoretical framework for interpreting the data. It then presents the methodology of the study including a brief profile of who enters teaching. This is followed by the presentation of the findings of the study, concluding with a discussion of the main issues emerging.

\section{Motivations to teach: Review of the literature and theoretical framework}

This section unpacks the theoretical framework used to interpret the data for the article. Scholars such as Lai (2011), Roness (2011), Eren (2012) and Christophersen et al. (2015) have noted several factors that motivate students to enter ITE programmes and become teachers. Motivation can be understood as a process or enactment of 'being moved, energised or activated to do something' according to Ryan and Deci (2000:54). Motivation encompasses the reasons that trigger or inspire behaviour that is characterised by the willingness and desire to act (Lai 2011). Motivation is thus a conduit for understanding behaviour. 'It involves a constellation of closely related beliefs, perceptions, values, interest, and actions' (Lai 2011:2).

It is evident that not all student teachers have similar motives for selecting teaching as a professional career (Jungert, Alm \& Thornberg 2014). An individual's choice to teach (and enter an ITE programme) might be motivated by a combination of individual factors as well as the social and cultural environment in which the education system is embedded (Tateo 2012).

Scholars examining motivation to enter ITE programmes identify several factors motivating individuals to enter teaching (Christophersen et al. 2015; Eren 2012; Lai 2011; Roness 2011). These factors largely relate to extrinsic and external factors; intrinsic factors relating to individual motivation and beliefs; and those which are classified as altruistic factors, which are closely linked to intrinsic factors but relate much more to the desire to do good (Deacon 2015). Extrinsic and intrinsic factors are arguably rooted in selfdetermination theory (STD), which distinguishes different types of motivation related to different reasons for actions (Deci \& Ryan 1985). However, as this article argues, the distinction between the latter two is not always clear-cut.

Extrinsic motivation emanates from instrumental reasons attached to rewards (Lai 2011; Ryan \& Deci 2000). For example, prospective teachers may be motivated by what they see as the material benefits or rewards that come from becoming a teacher, such as salary, vacations or other external rewards. The Funza Lushaka Bursary (FLB) (DoE 2009:5) offered to prospective students by the DBE in South Africa is an important extrinsic motivator. The FLB scheme, initiated in 2007 and introduced to stimulate enrolment in ITE (Van Broekhuizen 2015), provides for the full cost of tuition with the requirement that recipients enter the teaching career upon attainment of the qualification. From a teacher supply perspective, the FLB intervention appears to have had some success. Between 2007 and 2012, student teacher enrolment increased and graduation rates doubled (DHET 2013).

Eren (2012) argues that students' high school results may also be an extrinsic factor influencing their choice and serve as a motivator for becoming a teacher. In recent studies, young people indicated the following extrinsic factors as militating against the teaching profession: low salary and status (UNESCO 2015:202), unsafe teaching environments (violence), lack of learner respect for teachers, work overload and added responsibilities, and discouragement of students by their own teachers from following a career in teaching (Mutshaeni, Denhere \& Ravhuhali 2015:232; Ravhuhali 2010:103, 106).

Armstrong (2015) makes reference to the opportunity cost of becoming a teacher, which is determined by what an individual would earn in a different profession. These opportunity costs include hours worked and flexibility of schedules, as well as job stability further explaining the extrinsic dimension of motivation.

As already noted, the second category of motivation that is important to consider is intrinsic motivation. Several writers suggest that people are also motivated by issues of personal enjoyment, what interests them, the pleasure they derive 
from teaching and the activities related to the job itself. These are all essentially driven by the inherent satisfaction or the joy that comes from teaching and thus important intrinsic motivators (Lai 2011; Roness 2011; Ryan \& Deci 2000). The third category, altruistic motivation, may be understood as a subset of intrinsic motivation as noted above and is focused on viewing teaching as a socially worthwhile and important job, and a desire to be part of young people's growth and development (Christophersen et al. 2015:19). We discuss altruistic reasons for becoming a teacher as part of intrinsic motivation.

Studies show that student teachers are primarily motivated by intrinsic factors (Kyriacou \& Coulthard 2000) such as working with young people, the desire to make a difference to children's lives and society more broadly, a desire to maintain engagement with a subject area and an expectation of high levels of job satisfaction. The McKinsey survey of 2007 found that the common factor for teaching was helping a new generation succeed. These reasons have been described by some as idealistic, socially motivated or 'social justice' dimensions:

tacit in statements made by participants such as 'making a difference to children's lives' and 'helping others'; and these factors may well be implicit in the predominant responses of 'personal fulfilment' and 'working with young people'. (Manuel \& Hughes 2006:11)

It may also be that different kinds of motivations coalesce to influence a prospective teacher's reasons for entering an ITE programme. To further add complexity to the debates, factors motivating individuals to become teachers are contextually determined and framed, shaped by individual biography, positionality, beliefs and histories (Sayed \& Badroodien 2015). For example, a recent study of fourth-year B.Ed. and Post-Graduate Certificate in Education (PGCE) student teachers found that student teachers are altruistically and intrinsically motivated (Deacon 2015). The study showed that student teachers agreed or strongly agreed with the sentiment that they wanted to help improve the quality of education in South Africa, share their knowledge and help make a difference (Deacon 2015).

The factors or reasons that motivate individuals to become teachers may be divided into a set of push and pull factors. Push factors are those that explain motivation in relation to external and contingent factors which draw people into teaching, such as the promise of security, the absence of other career alternatives or teacher education as a route into higher education. Pull factors are those that seek to understand motivation in relation to individual desires and beliefs to do 'good' and 'contribute' to society as discussed below.

It is shown here that the literature on teacher motivation accommodates different spheres of influence acting on individuals' decisions to enter the teaching profession. Beyond the scope of this discussion, but of relevance to it, is the question of how these motivations are affected by different socioeconomic positions, responsibilities and deterrents. As such, perceptions of the profession are historically rooted and shaped by political, social and economic factors that affect its desirability and feasibility as a career. Because teaching has historically been characterised by lower pay (compared to doctors or lawyers) and less exclusivity than other professions because of the size of the teaching force (Bennell \& Akyeampong 2007), the strength of intrinsic and altruistic factors in drawing individuals to the profession is of particular importance here. The discussion now turns to a description of the methodology before presenting the findings of research.

\section{Methodology}

The data this article draws on are based on a longitudinal study of ITE conducted by the Centre for International Teacher Education since 2015 (Sayed \& Badroodien 2015). Quantitative data were collected using primarily a closedended questionnaire administered to first-year B.Ed. Foundation Phase student teachers at three public HE institutions in South Africa between May and October 2015. One institution is a traditional university and the other two are universities of technology. ${ }^{1}$ Two institutions are in one province and the third is in a different province. ${ }^{2}$ All students enrolled for B.Ed. Foundation Phase in the first year at the three institutions were selected to participate in the study. The questionnaire was administered during lectures where it was expected all students would be present. ${ }^{3}$ Ethical clearance was received from all institutions, and respondents participated freely in the study.

The questionnaire comprised two sections: the first section asked for biographical information and the second section focused on the respondents' reasons for entering the programme and their beliefs about teaching as a career. Student teachers were asked to report, on a Likert scale, how important 16 factors were in influencing their reason to become a teacher. Nine of the 16 items are reported and discussed in this article. ${ }^{4}$

In addition, students were asked three open-ended questions which further described their motivations to become teachers:

(1) Have we missed any experiences, feelings or ideas that you believe are important in terms of your choice to be a teacher? Please tell us about it.

(2) What are your expectations with regard to what you think you will learn in the years ahead as you learn to become a teacher?

(3) What are your anxieties with regard to your chosen career path in the years ahead?

1.In South Africa, a traditional university offers theoretically driven degrees, whereas universities of technology offer vocational oriented degrees.

2.For anonymity, institutions will not be named. Reference is made to Institutions 1,2 and 3 for explanatory purposes.

3.All lecturers who granted access to their lectures are acknowledged with gratitude.

4.A table is appended to the article presenting the results of the items discussed in this article. The items presented in the findings hold explanatory value with respect to the argument the article seeks to make. 
The questionnaire was administered in English at all institutions. A total of 383 respondents completed the questionnaire. Considered against the first year B.Ed. Foundation Phase enrolment figures for each of the institutions at the time, this translates into an $85 \%$ return rate. Data were first captured in Excel spreadsheets and then imported into Statistical Package for Social Sciences (SPSS). Analysis was thus aided by SPSS Version 23, 2015.

\section{Who enters teaching}

Of the 383 questionnaires, 109 (28.5\%) were completed by students from Institution 1, $217(56.8 \%)$ from Institution 2 and $56(14.7 \%)$ from Institution 3. The proportion of student teachers from each of the three institutions who completed the questionnaire is equal to their proportion in absolute enrolment figures. Table 1 provides a profile of who becomes a teacher using data drawn from the questionnaire responses and disaggregated by institution.

Of the respondents, $17.2 \%$ were speakers of African (or indigenous) languages (including isiXhosa, isiZulu, Sesotho, Setswana, Sepedi, isiNdebele, Tshivenda, Xitsonga and siSwati). The majority of the respondents' home language was Afrikaans (54\%), while $28.7 \%$ spoke English at home.

The findings related to home language mirror earlier data collected by the Department of Education (DoE 2006) and suggest that while the FLB has increased student teacher enrolment, an additional intervention is required to ensure that sufficient African language Foundation Phase teachers are supplied to the education system.

Of the respondents, $95.6 \%$ were female as noted in previous research (Hofmeyr \& Hall 1995; Mashiya 2014; Mukuna \& Mutsotso 2011; Petersen 2014). The feminisation of the teaching force at Foundation Phase level is underpinned by the idea that teaching in the Foundation Phase is equated to 'childcare' (Petersen 2014:1). Prospective female teachers see primary teaching as parenthood, while male teachers see primary teaching as mothering (Deacon 2012). The trend is not only confined to South Africa; in Tanzania, teaching at lower primary level is perceived as a low-status job meant for female teachers (Akyeampong et al. 2011). Jungert et al. (2014:182) attribute feminisation of the teaching force to female students having stronger altruistic motives than their male counterparts.

The majority of the respondents ( 289 or $78.1 \%$ ) were between the ages of 18 and 20 . Of the respondents, $18.9 \%$ (70) were

TABLE 1: Institutional distribution of respondents.

\begin{tabular}{llcc}
\hline Institution & & Frequency & $\mathbf{\%}$ \\
\hline Valid & Institution 1 & 109 & 28.5 \\
& Institution 2 & 217 & 56.7 \\
& Institution 3 & 56 & 14.6 \\
& Total & 382 & 99.7 \\
& missing & 1 & 0.3 \\
\hline Missing & & $\mathbf{3 8 3}$ & $\mathbf{1 0 0 . 0}$ \\
\hline
\end{tabular}

between 21 and 24 years, 1.6\% were between 25 and 27 years, and $1.3 \%$ (six respondents) were between 28 and 31 years.

Of the students who completed the questionnaire, $17.9 \%$ were identified as black students, $34.9 \%$ as mixed race students and $47.2 \%$ as white students.

The respondents in the study paid their tuition fees from a number of sources. The majority were, however, funded by their families $(53.3 \%)$. It is interesting to note that these findings showed the same percentage of students who were receiving government bursaries as Van Broekhuizen (2015) had found in his study, namely $11 \%$.

\section{Motivation to enter Bachelor of Education Foundation Phase programmes: Findings}

In the following section, we report on the reasons for entering teaching focusing on the extrinsic and intrinsic dimensions outlined above. Table 2 reports on the responses to the items about reasons for entering teaching across all the institutions.

TABLE 2: Reasons for becoming a teacher.

\begin{tabular}{|c|c|c|c|}
\hline Variable & & Frequency & $\%$ \\
\hline Teachers are well paid & $\begin{array}{l}\text { No importance } \\
\text { Low importance } \\
\text { Moderate Importance } \\
\text { High importance } \\
\text { No response } \\
\text { Total }\end{array}$ & $\begin{array}{c}123 \\
164 \\
73 \\
19 \\
4 \\
\mathbf{3 8 3}\end{array}$ & $\begin{array}{r}32.1 \\
42.8 \\
19.1 \\
5.0 \\
1.0 \\
100.0\end{array}$ \\
\hline $\begin{array}{l}\text { Teachers have good job } \\
\text { security }\end{array}$ & $\begin{array}{l}\text { No importance } \\
\text { Low importance } \\
\text { Moderate Importance } \\
\text { High importance } \\
\text { No response } \\
\text { Total }\end{array}$ & $\begin{array}{c}32 \\
79 \\
162 \\
103 \\
7 \\
383\end{array}$ & $\begin{array}{r}8.4 \\
20.6 \\
42.3 \\
26.9 \\
1.8 \\
100.0\end{array}$ \\
\hline $\begin{array}{l}\text { Teachers can always } \\
\text { find a job }\end{array}$ & $\begin{array}{l}\text { No importance } \\
\text { Low importance } \\
\text { Moderate Importance } \\
\text { High importance } \\
\text { No response } \\
\text { Total }\end{array}$ & $\begin{array}{c}41 \\
78 \\
145 \\
114 \\
5 \\
\mathbf{3 8 3}\end{array}$ & $\begin{array}{r}10.7 \\
20.4 \\
37.9 \\
29.8 \\
1.3 \\
100.0\end{array}$ \\
\hline $\begin{array}{l}\text { I received funding to study } \\
\text { to be a teacher }\end{array}$ & $\begin{array}{l}\text { No importance } \\
\text { Low importance } \\
\text { Moderate Importance } \\
\text { High importance } \\
\text { No response } \\
\text { Total }\end{array}$ & $\begin{array}{c}282 \\
38 \\
21 \\
34 \\
8 \\
383\end{array}$ & $\begin{array}{r}73.6 \\
9.9 \\
5.5 \\
8.9 \\
2.1 \\
100.0\end{array}$ \\
\hline $\begin{array}{l}\text { As a teacher I can influence } \\
\text { social cohesion in schools }\end{array}$ & $\begin{array}{l}\text { No importance } \\
\text { Low importance } \\
\text { Moderate Importance } \\
\text { High importance } \\
\text { No response } \\
\text { Total }\end{array}$ & $\begin{array}{c}7 \\
30 \\
163 \\
177 \\
6 \\
383\end{array}$ & $\begin{array}{r}1.9 \\
8.0 \\
42.6 \\
46.2 \\
1.6 \\
100.0\end{array}$ \\
\hline $\begin{array}{l}\text { As a teacher I can } \\
\text { contribute to enhancing } \\
\text { reconciliation }\end{array}$ & $\begin{array}{l}\text { No importance } \\
\text { Low importance } \\
\text { Moderate Importance } \\
\text { High importance } \\
\text { No response } \\
\text { Total }\end{array}$ & $\begin{array}{c}10 \\
57 \\
163 \\
146 \\
7 \\
383\end{array}$ & $\begin{array}{r}2.6 \\
14.9 \\
42.6 \\
38.1 \\
1.8 \\
100.0\end{array}$ \\
\hline $\begin{array}{l}\text { Teachers are important to } \\
\text { the future of our country }\end{array}$ & $\begin{array}{l}\text { No importance } \\
\text { Low importance } \\
\text { Moderate Importance } \\
\text { High importance } \\
\text { No response } \\
\text { Total }\end{array}$ & $\begin{array}{c}3 \\
11 \\
40 \\
327 \\
2 \\
383\end{array}$ & $\begin{array}{r}0.8 \\
2.9 \\
10.5 \\
85.8 \\
0.5 \\
100.0\end{array}$ \\
\hline $\begin{array}{l}\text { I can help my community } \\
\text { as a teacher }\end{array}$ & $\begin{array}{l}\text { Low importance } \\
\text { Moderate Importance } \\
\text { High importance } \\
\text { No response } \\
\text { Total }\end{array}$ & $\begin{array}{c}7 \\
80 \\
295 \\
1 \\
\mathbf{3 8 3}\end{array}$ & $\begin{array}{r}1.8 \\
20.9 \\
77.0 \\
0.3 \\
100.0\end{array}$ \\
\hline $\begin{array}{l}\text { Teachers are respected in } \\
\text { the community }\end{array}$ & $\begin{array}{l}\text { No importance } \\
\text { Low importance } \\
\text { Moderate importance } \\
\text { High importance } \\
\text { No response } \\
\text { Total }\end{array}$ & $\begin{array}{c}33 \\
117 \\
153 \\
71 \\
9 \\
383\end{array}$ & $\begin{array}{r}8.6 \\
30.5 \\
39.9 \\
18.5 \\
2.3 \\
100.0\end{array}$ \\
\hline
\end{tabular}




\section{Extrinsic dimension}

The data about extrinsic reasons for study reveal two interesting features. Firstly, the data suggest that $73.6 \%$ of respondents rated receiving funding as not important to their choice of becoming a teacher. Only $9.1 \%$ of respondents rated funding as a highly important factor in their decision to become teachers, which tallies well with the figure of $11 \%$ of first-year students receiving FLBs. The findings suggest that bursaries are not attracting the majority of student teachers into the profession. For those who are receiving bursaries, financial concerns to study are however considerable. The following comments of students in connection with waiting to receive a bursary exemplify financial concerns of students:

'I am afraid that I will be forced to drop out of the course as I have not received any of the bursaries I applied for and I'm therefore unable to pay as my parents cannot afford it.' (Participant from Institution 2, female, first-year student teacher)

'My biggest concern is not getting a bursary as my family lacks the funds for the small things even taxi fare.' (Participant from Institution 2, female, first-year student teacher)

'I am scared that I will not be able to pay for my studies if I should not receive a bursary for my next three years of studying.' (Participant from Institution 1, female, first-year student teacher)

Student teachers identified as black and student teachers from one university of technology are much less likely to rate having received funding as not important in the decision to become a teacher. This is illustrated in graphs that disaggregate the data from the questionnaire by race and institution (Figures 1 and 2).

Similarly, the level of salary, reflecting the current salary dispensation in South Africa perhaps, was not a key motivator to enter teaching. Over $74 \%$ of respondents rated 'teaching as a well-paid profession' as not being significant in their decision to enter teaching. ${ }^{5}$

Secondly, other extrinsic factors impacted students' desire to enter teaching. In particular, two factors, namely 'teachers have good job security' and 'can always find a job', were rated as important. Almost $70 \%$ of students rated good job security as important. ${ }^{6}$ Over $67 \%$ of students rated the availability of work as important. ${ }^{7}$

Students however expressed anxieties related to both salary and job security. As captured in the following open-ended response:

'Teachers are not well funded and I worry that, with the salary I will be receiving, I will not be able to properly fund my family in future.' (Participant from Institution 1, female, first-year student teacher)

5.The reason "teachers are well-paid" was rated of low importance and of no importance by $42.8 \%$ and $32.1 \%$ of respondents, respectively. For $5 \%$ of respondents, salary was a highly important factor and for almost $20 \%$ it was moderately important as a factor in their choice to become teachers.

6.Of the respondents, $42.3 \%$ rated good job security as moderately important and $26.9 \%$ rated this item highly important as a factor in their choice to become a teacher.

7.Job availability was rated of moderate importance by $37.9 \%$ ), high importance by $29.8 \%$, low importance by $20.4 \%$ and no importance by $10.7 \%$ of respondents.

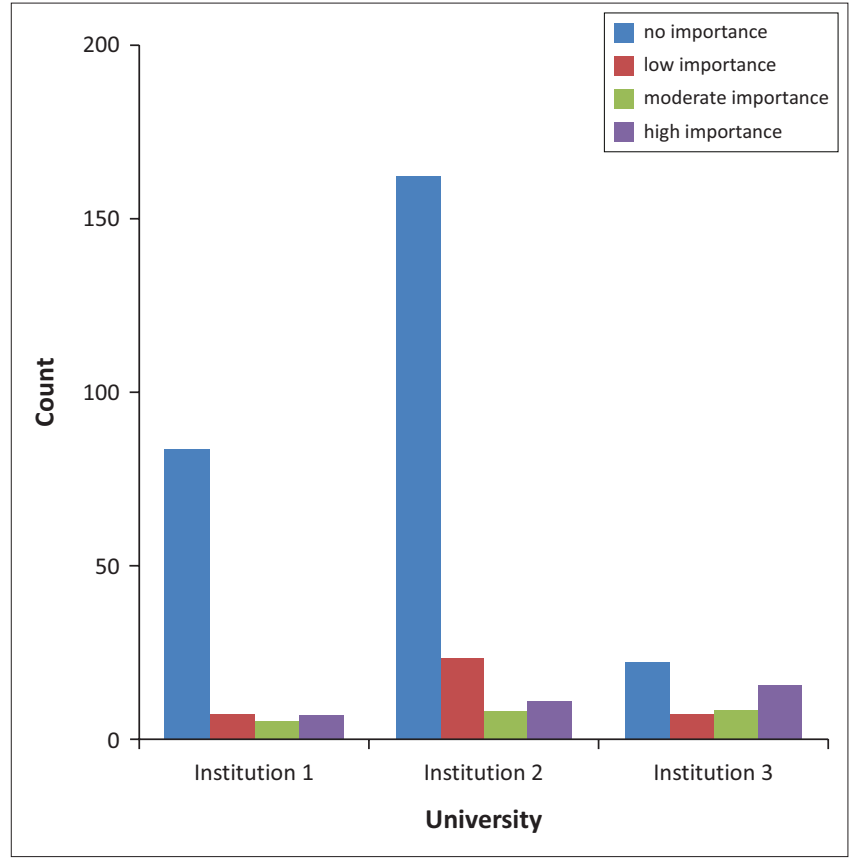

FIGURE 1: Graph illustrating response to 'I received funding ...' by institution.

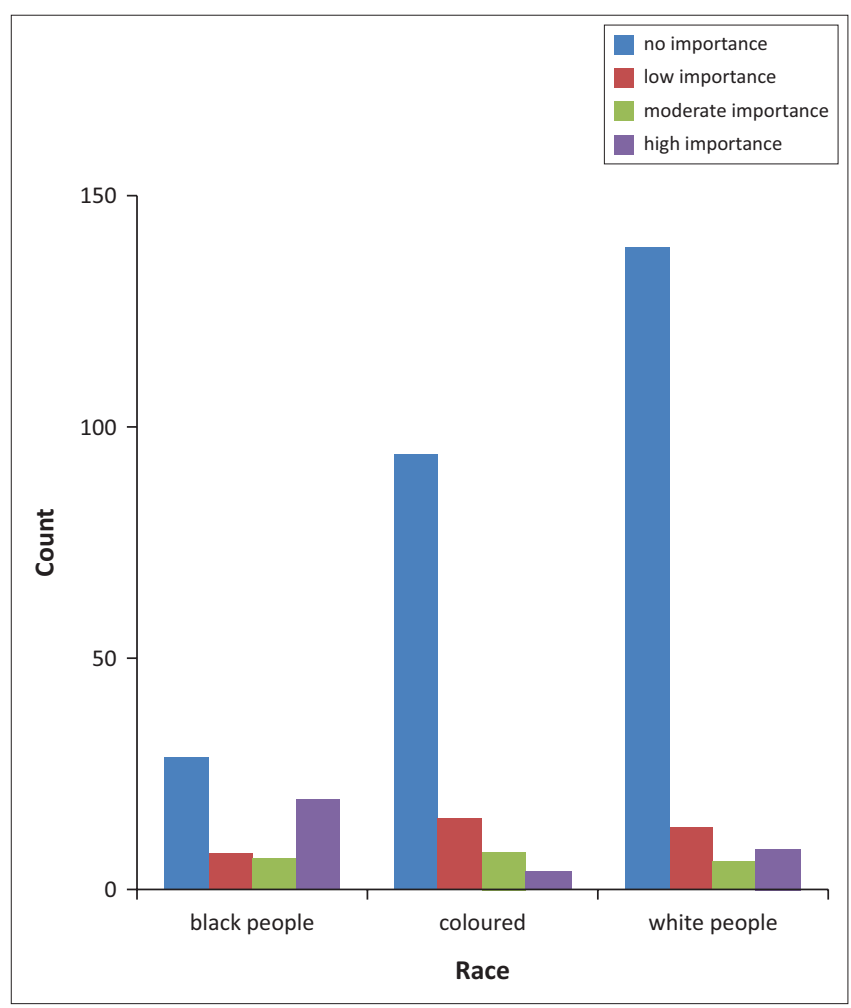

FIGURE 2: Graph illustrating response to 'I received funding ...' by race.

The above data suggest that the availability of funding and future salary expectations were not a significant driver of individuals' entry into the teaching profession, even though it was evident that financial matters were a cause for concern for some students. What was considered more important was the sense of stability around the teaching career, and whether it could offer consistency and security to graduates. Where job security is a widespread problem in the economy, the attractiveness of a stable career and relative ease in finding a work can be a key 
motivator for entering the teaching profession (Bennell and Akyeampong 2007).

\section{Intrinsic and altruistic motivation}

As noted above, intrinsic motivation is discussed as also encompassing the altruistic reasons that individuals offered for becoming teachers. There are three important findings regarding intrinsic and altruistic reasons for entering the teaching profession.

Firstly, the results indicate that over $80 \%{ }^{8}$ of students accorded moderate or high importance to teaching as an admirable profession as the reason for choosing to become teachers. Rating teaching moderately and highly as an admirable profession would suggest that it is an important intrinsic reason why many students choose to become teachers. The idea of teaching being a valued profession for which passion is a driving force is captured in the following open-ended comments by different participants:

'A personal desire to become a teacher; a true passion for teaching.' (Participant from Institution 2, female, first-year student teacher)

'The thing that is being missed out is if we enjoy it [teaching] and it [teaching] is our passion.' (Participant from Institution 2, female, first-year student teacher)

'So what you have missed in the factors is the joy of little one's or of teaching in general.' (Participant from Institution 2, female, first-year student teacher)

'Passion is very important to have since teaching is not as easy as it seems, I am very passionate about children and am fascinated by their growth and development.' (Participant from Institution 1 , female, first-year student teacher)

'I believe in order to be the best teacher possible you have to be extremely passionate about children and your subject(s). Every teacher should strive to be the best teacher in the school in which they are working or in their community/country.' (Participant from Institution 1, female, first-year student teacher)

Teachers being admired and respected only entered into isolated responses in students' own words. Secondly and closely related to the idea of being an admirable profession and having a passion for teaching is the fact that the majority of the student teachers $(85.8 \%)$ rated the item 'teachers are important to the future of our country' as a highly important factor for their reason to become teachers. ${ }^{9}$ The majority of the respondents $(77 \%)$ rated the item 'they can help their communities as teachers' as a highly important factor in their reason to become teachers. ${ }^{10}$

8.0 f the respondents, $50.1 \%$ accorded high importance to teaching as an admirable profession as the reason for choosing to become teachers and $38.1 \%$ accorded moderate importance for the same.

9. Of the students, $85.8 \%$ rated 'teachers are important to the future of the country' as highly important in their choice to become a teacher. A further $10.5 \%$ of students rated this as moderately important. Only $0.2 \%$ of students rated this as not important in their choice to become a teacher.

10.Of the students $85.8 \%$ rated 'I can help my community as a teacher' as highly important in their choice to become a teacher. A further $20.9 \%$ of students rated this item as moderately important. No students rated 'I can help my community as a teacher' as of no importance in their choice to become a teacher.
Crucial to the idea of contributing to national development is the fact that over $88 \%$ of respondents ${ }^{11}$ rated as important the idea that 'influencing social cohesion in schools' is a key reason for entering teaching. Over $80 \%$ of respondents ${ }^{12}$ rated 'the need to contribute towards enhancing reconciliation' as an important factor.

The relatively high importance given to such altruistic reasons suggests that B.Ed. Foundation Phase students seek to join the teaching profession to 'serve children, your community and your country' (DoE 2009:1). Open-ended responses elaborated on the idea of contributing to national and societal development, working with children and building the future, as follows:

'We also have a passion to make a difference in the lives or future of children in South Africa.' (Participant from Institution 2, female, first-year student teacher)

'Feeling that you, as a teacher, get to educate the future generation.' (Participant from Institution 2, female, first-year student teacher)

'I did not know that I want to be a teacher. All I know is that I want to be around children, I want to make a difference in their lives. A difference I wish someone made in my life growing up.' (Participant from Institution 2, female, first-year student teacher)

'We have the ability to change the minds of young people and this is important.' (Participant from Institution 2, female, firstyear student teacher)

'I love children. I love how to experience the world. I love being around children and talking to them on their levels. When I am sitting teaching children I feel the happiest and this is why I want to be a teacher. It is also because I want to have a positive effect on the lives of others.' (Participant from Institution 2, female, first-year student teacher)

'I love children and working with them. I worked with children for two years at a pre-school and I loved it. I want to make a change in the lives of children and inspire them to achieve their dreams.' (Participant from Institution 1, female, first-year student teacher)

'I hope that I will realise even more the impact that I can make on children's lives in the future.' (Participant from Institution 1, female, first-year student teacher)

Yet contributing to building the future was no easy ambition and many felt anxious as the following open-ended comments suggest:

'My anxiety is that I won't make any difference in a learner's life or that society brings our next generation so down that a teacher won't be able to make it better.' (Participant from Institution 2, female, first-year student teacher)

'I wonder if I will be a good teacher because I want the children in this country to have a good education.' (Participant from Institution 2, female, first-year student teacher)

'I might not do a good job or not be as influential as [I] thought [I] would be. It's [teaching] a huge responsibility to shape the future of our country.' (Participant from Institution 1, female, first-year student teacher)

11.A total of $42.6 \%$ students rated "I can influence social cohesion as a teacher" as moderately important and $46.2 \%$ rated this as highly important.

12.Of the respondents, $42.6 \%$ rated the need to enhance reconciliation as a factor of moderate importance, while $38.1 \%$ rated this as a high-importance item. 
The above data suggest that respondents felt teachers had an important role to play in learners' lives and could offer a positive influence over them and the challenges they faced elsewhere. They recognised that poor teaching and teachers would negatively impact vulnerable learners and expressed anxieties about whether they were capable of performing a role invested with so much responsibility. The perception of the profession as one of great moral and social importance contributed to the positivity with which respondents viewed their future careers.

\section{Discussion of findings}

The DBE in South Africa is committed to providing quality education to all learners and ensuring a better future for all. Sufficient teachers are needed in order to achieve this. Consequently, South Africa needs a pool of zealous, inspired, creative, top-achieving Grade 12 learners and prospective students to pursue studies in education (De Beer 2013). A goal of the DBE is thus to attract a new group of young, motivated and appropriately trained teachers into the teaching profession each year (DBE 2015). Understanding student teachers' reasons for entering ITE programmes is important for maintaining adequate enrolment levels or a supply at that level. The findings from this survey contribute to our understanding of what motivates student teachers to enter ITE Foundation Phase programmes (Van Broekhuizen 2015).

South Africa has a particular problem of teacher supply in the Foundation Phase. A recent estimate using a multivariate model suggested that there will be a negative gap of Foundation Phase teachers of between 15220 and 42135 by 2020, accumulating over the years from 2013 to 2019 (Green et al. 2014). The authors indicated that the public HE system can be expected to produce no more than 3880 new Foundation Phase ITE graduates by 2019. Attention to what motivates student teachers to enter the profession in the Foundation Phase would contribute to ensuring an adequate supply.

The data presented in the article show that student teachers are motivated by both extrinsic and intrinsic factors to enrol in a B.Ed. Foundation Phase programme. As in other studies, however, the data suggest a complex and nuanced set of motivations to enter teaching. Specifically, this article drawing on extrinsic and intrinsic dimensions of motivation within STD (Ryan \& Deci 2000) outlined multiple and varied reasons. Managing teacher supply and demand is thus complex and dynamic, challenging simplistic and prescriptive models of supply and demand.

An external motivating factor at the outset of teacher education - the availability of bursaries - can be a crucial factor in ensuring an adequate teacher supply. Financial assistance is of particular importance for students who can teach in an African language, where the greatest shortage lies (Green et al. 2014:5, 18-20). All prospective student teachers who require financial aid would benefit from increased funding, thus enhancing supply.
Student teachers overwhelmingly rated contributing to the future of the country as highly important in their decision to become teachers. Given that other studies have found similar results with respect to altruistic reasons, answers to these questions are important for adequate management of teacher supply. Although altruism is a key driver for enrolment in ITE programmes, students expressed anxieties both with respect to the conditions of teaching and with respect to their ability to provide for their families on a teacher's salary. Extrinsic reasons are thus constant factors that may impact teacher supply. Kyriacou et al. (1999: 374) find that 'when national economies are buoyant, and jobs other than teaching are more readily available, the number of high quality applicants to teacher training tends to decrease'. Relatively low teacher salaries therefore present a constant challenge to maintaining a consistent and consistently skilled cohort of graduate teachers, particularly where student teachers may be able to secure funding for higher status professions with promises of greater economic returns (Kyriacou et al. 1999).

The relationship between teacher supply and salary has implications for the responses on teacher salaries. While respondents did not emphasise 'teaching is a well-paid profession' in the survey, low teacher salaries could also account for negative impressions of the financial benefit and explain why salaries are not important for aspiring teachers (SACE 2010). Being unconcerned about salary resonates with the data on respondents' intrinsic and altruistic motivators, which suggest that student teachers may be idealistic about what constitutes their future career and thus not adequately prepared for the realities and challenges faced by learners and schools. Teachers aged between 30 and 49 account for $43 \%$ of all terminations from the teaching profession, largely resignations (SACE 2010). Between 30 and 49 may be where teachers realise they are not able to accomplish changing society, and compromising financial security is no longer logically viable.

Further research is needed on the motivations for early attrition, but it is arguable that the match between student teachers' motivations for entering the profession and the congruence of making a difference with the realities they encounter is of crucial importance. Low job satisfaction and job security was also cited by teachers in SACE's (2010) study as important reasons why they were considering leaving the profession. Given that student teachers want to contribute to building a better future, an inability to do so would lead to low job satisfaction. Lui Xi (2016:37-38) contends that 'an autonomy-supportive context tends to maintain or enhance intrinsic motivation'. Where teachers are not supported in their pursuit to make a difference, job satisfaction would be low and this explains their flight under conditions that are at odds with their assumptions of the profession in the first place.

Sustainable teacher supply will be possible if the education system provides conditions in which teachers are able to contribute to improving young people's lives and make a 
difference. If intrinsic reasons are linked to salaries that allow a decent standard of living, teacher supply is likely to be less of a challenge. Improving teacher salaries cannot, however, take place in isolation from improving the environments in which teachers teach (SACE 2010). Incumbent teachers cite challenging teaching contexts as a key factor influencing job satisfaction (SACE 2010). Improving environments would moreover support teachers to accomplish their desire to improve the lives of children. Maintaining teacher supply therefore depends on a range of system-wide factors, including well-functioning schools capable of meeting student teachers' aspiration to be agents of change, and a supportive policy and professional environment that enables them to work in challenging contexts. Given the challenge of supply at the Foundation Phase, respective system-wide factors should take effect here first.

\section{Conclusion}

The picture that emerges from the data of this study is that motivations to become a teacher are varied and complex, which can be attributed to both extrinsic and intrinsic factors. Dominant extrinsic determinants were on the whole mainly financial, related to work security and the need to function in a stable work environment. Intrinsic factors such as passion for teaching and supporting and working with young children as well as doing good for society and the community suggest prospective teachers are not without strong altruistic reason to teach.

The research reported in this article indicates that future teachers are neither self-seeking individuals nor wholly motived by intrinsic and altruistic factors. But on balance they exhibit a stronger desire and passion to serve and assist others, particularly young children. As such there is much for policymakers and teacher education providers to build on to make teaching an attractive profession and one that redresses the historic and structural inequities in society. To this end, teacher education providers need to nurture and sustain the positive motivation of those choosing teaching as a career option developing dispositions that build on the enthusiasm for supporting young children that these cohorts demonstrate. Policymakers need to nurture a culture of teaching as a positive and highly esteemed profession. Moreover, both providers and policymakers need to recognise the importance of teachers in schools as important role models for prospective teachers. Further, much work needs to be conducted to ensure more black and male Foundation Phase teachers join the teaching profession, which for many young children is their first encounter with learning and teaching.

\section{Acknowledgements}

We hereby acknowledge and express gratitude to the Centre for International Teacher Education (CITE), Cape Peninsula University of Technology (CPUT), and the National Research Foundation's (NRF) support for the South African
Research Chair (SARChI) which made this research possible. We record, however, that all views expressed in this article reflect the views of the authors alone and do not represent the position of CITE, the NRF: South Africa, or any other funders.

This research was supported by the NRF, which funds the SARChI in Teacher Education, CPUT.

\section{Competing interests}

The authors declare that they have no financial or personal relationships which may have inappropriately influenced them in writing this article.

\section{Authors' contributions}

Y.S. was the principal investigator, Y.S. and Z.M. led the team that administered the instrument and conducted the analysis. Y.S. and Z.M. made conceptual contributions as well as writing the article.

\section{References}

Akyeampong, K., Pryor, J., Westbrook, J. \& Lussier, K., 2011, Teacher preparation and continuing professional development in Africa: Learning to teach early reading and mathematics, Centre for International Education, University of Sussex, viewed 26 May 2015, from www.sussex.ac.uk/cie/documents/tpa-synthesisreport-july(2011).pdf

Armstrong, P., 2015, Teachers in the South African education system: An economic perspective, Econex Research Note 39 October 2015, viewed 01 December 2015, from http://econex.co.za/wp-content/uploads/2015/10/ECONEX_researchnote_ 39.pdf

Bennell, P. \& Akyeampong, K., 2007, Teacher motivation in sub-Saharan Africa and South Africa, DfID, London.

Christophersen, K.-A., Elstad, E., Solhaug, T. \& Turmo, A., 2015, 'Gender variations in Norwegian pre-service teachers' motivational orientations', Problems of Education in the 21st Century 63(2015), 17-28.

Deacon, R., 2012, The Initial Teacher Education Research Project: The initial professional development of teachers: A literature review, JET Education Services, Johannesburg.

Deacon, R., 2015, Initial Teacher Education Research Project: Report on the 2013 survey of final year initial teacher education students, JET Education Services, Johannesburg.

De Beer, J., 2013. 'Challenging students' perceptions of what it means to become a teacher: Annual first-year excursion', EDUBRIEF@UJ 9(1), 4-5.

Deci, E.L. \& Ryan, R.M., 1985, Intrinsic motivation and self-determination in human behaviour, Plenum, New York.

Department of Basic Education (DBE), 2015, Action Plan to 2019: Towards the realisation of schooling 2030. Taking forward South Africa's National Development Plan 2030, DBE, Pretoria.

Department of Education (DoE), 2006, Recruitment and retention policy to address scarcity of School Educators in Certain Subject Areas and Certain Geographical Areas, DoE, Pretoria.

Department of Education (DoE), 2009, Information guide on Initial Teacher Education, DoE, Pretoria.

Department of Higher Education and Training (DHET), 2013, Trends in teacher education 2012, DHET, Pretoria.

Eren, A., 2012, 'Prospective teachers' interest in teaching, professional plans about teaching and career choice satisfaction: A relevant framework?', Australian Journal of Education 56(3), 303-318. https://doi.org/10.1177/ 000494411205600308

Green, W., Adendorff, M. \& Mathebula, B., 2014, “'Minding the Gap?” A nationa foundation phase teacher supply and demand analysis: 2012-2020', South African Journal of Childhood Education 4(2), 1-23.

Hofmeyr, J. \& Hall, G., 1995, The national teacher education audit: Synthesis report, Centre for Educational Policy Development, Pretoria.

Jungert, T., Alm, F. \& Thornberg, R., 2014, 'Motives for becoming a teacher and their relations to academic engagement and dropout among student teachers', Journal of Education for Teaching 40(2), 173-185.

Kyriacou, C. \& Coulthard, M., 2000, 'Undergraduates' views of teaching as a caree choice', Journal of Education for Teaching 26(2), 117-126. https://doi. org/10.1080/02607470050127036 
Kyriacou, C., Hultgren, A. \& Stephens, P., 1999, 'Student teachers' motivation to become a secondary school teacher in England and Norway', Teacher Development 3(3), 373-381. https://doi.org/10.1080/13664539900200087

Lai, E.R., 2011, Motivation: A literature review research report, viewed 19 August 2015, from http://images.pearsonassessments.com/images/tmrs/Motivation Review_final.pdf

Manuel, J. \& Hughes, J., 2006, “"It has always been my dream": Exploring pre-service teachers' motivations for choosing to teach', Teacher Development 10(1), 5-24. https://doi.org/10.1080/13664530600587311

Mashiya, N., 2014, 'Becoming a (male) Foundation Phase teacher: A need in South African schools?', South African Journal of Childhood Education 4(3), 24-36. https://doi.org/10.4102/sajce.v4i3.224

Mourshed, M., Chikjioke, C. \& Barber, M., 2010, How the world's most improved school systems keep getting better, McKinsey and Company, London.

Mukuna, T.E. \& Mutsotso, S.N., 2011, 'Gender inequalities in early childhood development education teaching profession in Kenya', Educational Research 2(13), 1876-1885.

Mutshaeni, H.N., Denhere, C. \& Ravhuhali, F., 2015, 'High school students' attitudes towards the teaching profession', Journal of Sociology and Social Anthropology 6(2), 227-233.

Petersen, N., 2014, 'The "good," the "bad" and the "ugly"? Views on male teachers in Foundation Phase education', South African Journal of Education 34(1), 1-13. https://doi.org/10.15700/201412120926

Ravhuhali, F., 2010, 'Attitudes of high school students towards the teaching profession', MEd thesis, University of Venda, Thohoyandou.
Roness, D., 2011, 'Still motivated? The motivation for teaching during the second year in the profession', Teaching and Teacher Education 27(2011), 628-638. https:// doi.org/10.1016/j.tate.2010.10.016

Ryan, R.M. \& Deci, E.L., 2000, 'Intrinsic and extrinsic motivations: Classic definitions and new directions', Contemporary Educational Psychology 25, 54-67.

SACE, 2010, A review of teacher supply and demand. Identifying research gaps and the role of SACE, SACE, Pretoria.

Sayed, Y. \& Badroodien, A., 2015, Unpublished concept note: Longitudinal study of initial teacher education, CITE, CPUT, Cape Town.

Tateo, L., 2012, "What do you mean by "teacher"? Psychological research on teacher professional identity', Psicologia \& Sociedade 24(2), 344-353. https://doi. org/10.1590/S0102-71822012000200012

Thomson, M., Turner, J. \& Nietfeld, J., 2012, 'A typological approach to investigate the teaching career decision: Motivations and beliefs about teaching of prospective teacher candidates,' Teaching and Teacher Education 28(2012), 324-335. https:// doi.org/10.1016/j.tate.2011.10.007

United Nations Educational, Scientific and Cultural Organization (UNESCO), 2015, Education for all (EFA): Global monitoring report 2000-2015, achievements and challenges, UNESCO, Paris.

Van Broekhuizen, H., 2015, Teacher supply in South Africa: A focus on initial teacher education, Working paper, Stellenbosch University, Stellenbosch.

World Bank, 2012, System Approach for Better Education Results (SABER): What matters most in teacher policies? A framework for building a more effective teaching profession, World Bank, Washington, DC.

Xi, L. \& Wen-ying, M., 2016, 'A new view on teaching motivation - Self-determination theory', Sino-US English Teaching 13(1), 33-39. 